\title{
STUDIES ON FAT BODY PROTEIN AND COMMERCIAL CHARACTERS OF THE SILKWORM, BOMBYX MORI L. TREATED WITH JUVENILE HORMONE MIMIC
}

\author{
R. S. UMAKANTH* \& NAVYA, K. \\ Biochemical Genetics Lab, Post-Graduate Department of Studies in Sericulture Science, \\ University of Mysore, Manasa Gangothri, Mysuru, India
}

\begin{abstract}
In all organisms, the endocrine system serves as an important link between the environment and various physiological activities. The brain plays vital role in regulating the growth, development and reproduction of all prokaryotes and eukaryotes. In mulberry silkworm Bombyx mori, the Juvenile Hormone (JH) is secreted by corpora allatum and JH has a functional role in larval life, metamorphosis, reproduction, behaviour, diapause and communication. Proteins are important bio molecules, which play key role in the growth and development as well as silk biosynthesis, which are absorbed from mulberry leaf and get accumulated in various tissues viz., fat body, haemolymph and silk glands of the silkworm.

Three popular bivoltines, of which two hybrids $F C_{1}$ and $F C_{2}$ and a double hybrid $F C_{1} X \mathrm{FC}_{2}$ were selected for the present investigation. The $5^{\text {th }}$ instar silkworm larvae (day three and day five) were utilised for exogenous administration of juvenile hormone analogue (Samrudhi) in three different concentrations 15, 20 and $25 \mu l$ and their fat body was collected after 24, 48 and $72 \mathrm{~h}$. of treatment along with control and absolute control. The samples were subjected to quantitative estimation of total protein following Lowry's et al. (1951) method. The results clearly show that gradual increase in the protein content along with the increase in concentration of $J H(15,20$ and $25 \mu l)$ in both the hybrids and double hybrid under study. The protein content is higher in double hybrid $F_{1} \mathrm{XFC}_{2}$, followed by the hybrids $\mathrm{FC}_{2}$ and $\mathrm{FC}_{1}$. The larval duration, cocoon and shell weight, filament length exhibited marginal increase as the concentration of JH treatments.
\end{abstract}

KEYWORDS: Juvenile hormone, Protein, Bombyx mori, fat body

Received: Feb 07, 2021; Accepted: Feb 27, 2021; Published: Mar 12, 2021; Paper Id.: IJASRAPR20216

\section{INTRODUCTION}

Sericulture is large scale rearing of silkworms for the production of silk fibre due to its high economic value. There are several species of silkworms exploited commercially, while Bombyx mori is the most widely used and intensively studied. Sericulture comprises of multiple activities like moriculture, silkworm seed production, silkworm rearing, marketing of cocoons, silk reeling, marketing of raw silk, silk weaving. In India, Sericulture industry provides employment to approximately 8 million persons in rural and semi-urban areas. After China, India is the next largest producer of silk in the world, among the four varieties of silks produced, during 2019-20 the mulberry silk accounts for 25239 MT (70.46\%), Tasar 3136 MT (8.75\%), Eri 7204 MT (20.11\%) and Muga 241 MT $(0.67 \%)$ of the total raw silk production of 35820 MT.

Proteins are important bio-molecules which are required for growth and development of the silkworm as well as for the biosynthesis of silk. The proteins get accumulated in various forms as fat body protein, haemolymph 
protein and silk protein in the silkworm larvae. These proteins are obtained from mulberry leaf, which is the sole food for the silkworm, B. mori. The fat body can be found distributed irregularly in the per-visceral space of the abdomen and thorax surrounding the internal organs of the abdomen close to the integument. The fat body synthesizes a number of proteins and releases them into the haemolymph during active feeding (larval) stage (Kumar et al. 1998).

In insects, juvenile hormone $(\mathrm{JH})$ refers to a group of hormones, ensures the growth of the larvae by postponing the maturity. The rigidity of integument in insects hinders the growth during their development, hence shed their old integument and synthesize new one, this process is known as moulting. There are four moults during their larval period and juvenile hormone is secreted by a pair of endocrine glands called the corpora allatum present behind the brain. In 1956, Williams succeeded in extracting active juvenile hormone preparation from Hyalophora cecropia adults and its purification led to the discovery of juvenile hormone activity. The juvenile hormone $(\mathrm{JH})$ and 20-hydroxyecdysone (20E) regulates large number of processes in insects like metamorphosis and reproductive maturation; also behaviour, morphology, diapause, stress resistance, immune function and aging. Application of the juvenile hormone analogue (JHA) in the late larval stage can induce its prolongation which inhibits the initiation of larval-pupal differentiation (Sakurai and Imokowa, 1988). JH is commercially available in the brand name "samrudhi" used for exogenous application and to understand its effects on the silkworm, Bombyx mori L. Samruddhi has been reported to be a potent juvenile hormone analogue (JHA) against the silkworm, Bombyx mori (Kamimura and Kiuchi, 1998). The objective of the present study is to understand the deviations of the protein profiles in the fat body of Bombyx mori L. fed with mulberry leaf treated with $\mathrm{JH}$ mimic to the $5^{\text {th }}$ instar larvae in three different concentrations. In addition, to evaluate its influence on the protein content in the fat body during $5^{\text {th }}$ instar (day 3 ), to correlate the same with selected economic traits in treated and control batches.

\section{MATERIALS AND METHODS}

In the present study, the disease free layings of two bivoltine hybrids $\mathrm{FC}_{1}$ and $\mathrm{FC}_{2}$ and one double hybrid $\mathrm{FC}_{1} \mathrm{X} \mathrm{FC}_{2}$ supplied by Silkworm Seed Production Centre (SSPC), Central Silk Board, Mysuru a unit of National Silkworm Seed Organization were reared following the standard rearing methodology (Dandin and Giridhar, 2010). During the silkworm rearing, $\mathrm{V}_{1}$ variety from irrigated mulberry garden of Department of Sericulture Science, University of Mysore, Manasa Gangothri, Mysuru was fed to silkworm larvae thrice a day. The performance of various commercial characters were recorded during the silkworm rearing for evaluation and correlation with the results of the biochemical studies. The selected traits are matured larval weight, total larval duration, cocoon yield, single cocoon weight, single shell weight, shell ratio, filament length, filament weight were recorded. The temperature ranged between $26-30^{\circ} \mathrm{C}$ and the relative humidity was in the range of $55-70 \%$ during the period of rearing. By dissecting the silkworm larvae of day 3 of fifth instar, the fat body were collected in pre-chilled eppendorff tubes and these samples were used for protein estimation following the Lowry's et al. (1951) method.

\section{METHODOLOGY}

\section{Topical (Dermal) Application Method}

The larvae after $4^{\text {th }}$ moult were divided into five batches of 100 larvae each and all batches were maintained in three replications. The $3^{\text {rd }}$ day of fifth instar larvae were used for exogenous application of the juvenile hormone mimic (Samruddhi) by spraying with 15,20 and $25 \mu$ l concentrations before feeding in different batches. One batch was maintained as control by spraying distilled water and another batch served as absolute control without any treatment. The treated larvae were fed with $\mathrm{V}_{1}$ mulberry leaf followed by treatment on day 3 of $5^{\text {th }}$ instar. The fat body was dissected after 
24, 48 and $72 \mathrm{~h}$. after treatment of day 3, and was used for quantitative estimation of protein using spectrophotometric analysis. The protein content was estimated following the standard procedure of Lowry et al. (1951) after specified time of the treatment to understand the impact of the JH on the silkworm larval body. For accuracy in quantification, the sample protein was compared with known amount of a standard protein using Bovine Serum Albumin (BSA). The data obtained for all the batches pertained to amount of protein content present in the fat body was statistically analysed, correlated and interpreted.

\section{RESULTS}

The results obtained for protein content in bivoltine hybrids $\mathrm{FC}_{1}$ and $\mathrm{FC}_{2}$, double hybrid $\mathrm{FC}_{1} \mathrm{XFC}_{2}$ of treated, control and absolute control batches by adopting quantitative estimation using spectrophotometer was subjected to statistical analysis using standard deviation and error. This data was used to correlate with the results obtained for protein content in the fat body of $5^{\text {th }}$ instar larvae (day 3 ) understudy along with the commercial characters of silkworm rearing.

\section{Protein Content in Fat Body}

The fat body protein recorded a slightly higher activity in control over absolute control, while in case of treated batches using the three concentrations the activity shows a gradual increase from $15 \mu \mathrm{l}, 20 \mu \mathrm{l}$ and $25 \mu \mathrm{l}$. The protein content in the fat body $(\mathrm{mg} / \mathrm{g})$ is slightly higher in control than absolute control, while a gradual increase was seen in treated batches. The activity shows a higher trend as the concentration of the JH increases from $15 \mu \mathrm{l}, 20 \mu \mathrm{l}$ and $25 \mu \mathrm{l}$ in day 3 of $5^{\text {th }}$ instar larvae, samples were subjected to analysis after $24 \mathrm{~h}, 48 \mathrm{~h}$ and $72 \mathrm{~h}$ after treatment.

The mean values (mg/g) for $15 \mu \mathrm{l}$ treatment recorded were 18.25 in $\mathrm{FC}_{1}, 20.73$ in $\mathrm{FC}_{2}$ and 23.13 in $\mathrm{FC}_{1} \mathrm{XFC}_{2}$ after 24 hours of treatment. In case of samples analysed after 48 hours of treatment the values are 18.38 in $\mathrm{FC}_{1}, 20.85$ in $\mathrm{FC}_{2}$ and 24.85 in $\mathrm{FC}_{1} \mathrm{XFC}_{2}$. The samples used for analysis after 72 hours of treatment, the values are 19.28 in $\mathrm{FC}_{1}, 20.90$ in $\mathrm{FC}_{2}$ and 25.52 in $\mathrm{FC}_{1} \mathrm{XFC}_{2}$ were recorded. The mean values $(\mathrm{mg} / \mathrm{g})$ for $20 \mu \mathrm{l}$ concentration recorded were 18.76 in $\mathrm{FC}_{1}, 20.85$ in $\mathrm{FC}_{2}$ and 23.40 in $\mathrm{FC}_{1} \mathrm{XFC}_{2}$ after 24 hours of treatment. In case of samples analysed after 48 hours of treatment the values are 18.85 in $\mathrm{FC}_{1}, 20.96$ in $\mathrm{FC}_{2}$ and 24.92 in $\mathrm{FC}_{1} \mathrm{XFC}_{2}$. The samples used for analysis after 72 hours of treatment, the values are 19.80 in $\mathrm{FC}_{1}, 21.29$ in $\mathrm{FC}_{2}$ and 25.82 in $\mathrm{FC}_{1} \mathrm{XFC}_{2}$ were recorded. The mean values $(\mathrm{mg} / \mathrm{g})$ for $25 \mu$ concentration recorded were 19.26 in $\mathrm{FC}_{1}, 21.90$ in $\mathrm{FC}_{2}$ and 25.11 in $\mathrm{FC}_{1} \mathrm{XFC}_{2}$ after 24 hours of treatment. In case of samples analysed after 48 hours of treatment the values are 19.37 in $\mathrm{FC}_{1}, 21.28$ in $\mathrm{FC}_{2}$ and 25.08 in $\mathrm{FC}_{1} \mathrm{XFC}_{2}$. The samples used for analysis after 72 hours of treatment, the values are 20.11 in $\mathrm{FC}_{1}, 22.45$ in $\mathrm{FC}_{2}$ and 25.99 in $\mathrm{FC}_{1} \mathrm{XFC}_{2}$ were recorded. The values of control and absolute control along with the treated batches are presented graphically in figures 1,2, and 3 respectively. The mean values of selected economic traits of all the four treatments, control and absolute control are presented in tables 1 . $(\mathrm{P}<0.05)$.

\section{DISCUSSION}

Profound biochemical changes occur in the silkworm larvae in particular to the concentration of certain pools of proteins and amino acids during insect metamorphosis. The endocrinological studies of the fifth instar larval stage differ from those of other larval instars and are important for larval to pupal metamorphosis. The fat body also synthesizes a number of proteins and releases them into the haemolymph during active feeding (larval) stage (Kumar et al. 1998). JH can be suppressive or can induce protein synthesis independently or antagonistically (Fang et al. 2005). However, the juvenile hormone can also interact synergistically (Fang et al. 2005) and can also be effective to induce protein synthesis (Flatt $e t$ 
al. 2006). The JH is secreted during the fourth moult and then disappears from the haemolymph during early days of the fifth instar. The ecdysone levels during the first 3 days of the $5^{\text {th }}$ instar are not detectable, but juvenile hormone is still found in the haemolymph (Sakurai et al. 1998). Disappearance of juvenile hormone on day 3 is very much required for recovery of the prothoracic gland activity for the secretion of ecdysone. Both ecdysone and juvenile hormone can be found present in the haemolymph (Sakurai et al. 1989) after day 5 of the fifth instar. Juvenile hormone analogue leads to increase in concentration in the haemolymph protein and this result arises due to prevention of sequestration of storage proteins by the fat body of the silkworm, Bombyx mori (Kajiura and Yamashita, 1992). The juvenile hormone also controls the silk gland functioning, prevents their degeneration and can be directly responsible for increase in silk production (Sehnal and Akai, 1990). With this background, many researchers used JH mimics in Sericulture to enhance the silk productivity. The response of the silkworm larvae in relation to topical administration of the JH mimic depends on the dosage and time of treatment (Chowdhury et al., 1990).

The $\mathrm{JH}$ was tested as well as justified in respect to increase the rate of silk protein, along with the cocoon weight; shell weight as reported by Nair, et al., (2002). The economic characters of the silkworm breeds exhibited a positive response in juvenile hormone treated breeds in the development as reported by Muroga (1975). The results obtained clearly shows that JH mimicking compounds influence the silk production positively, it is dependent on the dosage and the time of application as stated earlier (Akai et al., 1988, Trivedi et al., 1993). In insects, juvenile hormone exhibits a regulatory effect on protein synthesis. JH and $20 \mathrm{E}$ can be both suppressive or can induce protein synthesis independently or antagonistically (Hiruma et. al., 1999; Zhou and Riddiford, 2002; Dubrovsky, 2005; Fang et al. 2005; Flatt et al. 2005). JH is secreted during the fourth moult and then gradually subsides in the haemolymph during early days of the fifth instar. Following this the JH titer increases gradually from day 5 until it completes the pupation (Niimi and Sakurai, 1997).

Effects of $\mathrm{JH}$ mimics on total protein content in fat body were analysed in the present study. It was observed that the protein content is higher in double hybrid $\mathrm{FC}_{1} \mathrm{XFC}_{2}$, followed by hybrids $\mathrm{FC}_{2}$ and $\mathrm{FC}_{1}$. There is a gradual increase in the protein as the concentration of the $\mathrm{JH}$ increases for 15, 20 and $25 \mu \mathrm{l}$ concentrations, which is observed in both the hybrids and double hybrid as higher protein content was recorded. The protein content is higher in control i.e., treated with distilled water than absolute control in both hybrids and the double hybrid under study. The results obtained clearly shows that use of JH mimics in commercial silkworm rearing is beneficial, can prolong the larval period, and adds to the silk content of the cocoon. The economic parameters show a gain in treated batches over control and absolute control, cocoon and shell weight along with filament length has increased as the concentration of JH increased. Among the three hybrids under study, $\mathrm{FC}_{1} \mathrm{XFC}_{2}$ showed higher larval weight, $\mathrm{FC}_{2}$ for shell weight, shell ratio and filament length was observed (Table 1). $\mathrm{FC}_{1}$ recorded the least values among all the three breeds understudy for all the traits. Larval duration prolonged by $3 \mathrm{~h}$. and $6 \mathrm{~h}$. in $\mathrm{FC}_{2}$ and $\mathrm{FC}_{1} \mathrm{XFC}_{2}$ respectively for treatments in larvae of day 3 . The results clearly shows that spraying of juvenile hormone mimics in commercial silkworm rearing is a beneficial aspect as it prolongs the larval duration and also adds to the silk content in the cocoon due to high consumption of mulberry leaf contributing to yield both qualitatively and quantitatively. This in turn gives higher productivity of silk per unit area and can fetch higher price based on the quality of cocoons as well as income to the farmers practicing sericulture.

\section{ACKNOWLEDGEMENTS}


The second author of this article is thankful to the Chairman, DoS in Sericulture Science, University of Mysore, Manasa Gangothri, Mysuru for the facilities provided to conduct the experiment.

\section{REFERENCES}

1. Akai, H., Kimur, K., Kiuchi, M. \& Shibukawa, A. (1985). Increase in silk production by repeated treatments with a Juvenile Hormone Analogue. J Sericulture Science in Japan, 54, 297-299.

2. Sanjay Agarwal, Ashok Kumar \& P. K. Singh, "Influence of Saline Water Irrigation on Crude Protein and Amino Acids in Two Genotypes of Finger Millet (Eleusine Coracana Gaertn)", International Journal of Agricultural Science and Research (IJASR), Vol. 6, Issue 5, pp, 261-268

3. Akai, H., \& Kobayashi, M. (1971). Induction of prolonged larval instar by the juvenile hormone in Bombyx mori L. (Lepidoptera: Bombycidace). Appl. Entomol. Zool., 6, 21938-1939.

4. Sadhna Chaturvedi, Tejovathi Gudipati \& Archna Shrivastav, "Analysis of Proline and MDA and Protein Profile in Seedlings of Cowpea Exposed to NaCl Salinity - Influence of Rhizobacterium on Salt Tolerance”, International Journal of Applied and Natural Sciences (IJANS), Vol. 6, Issue 4, pp; 97-106

5. Ananthbandhu Chaudhuri, Ashok Kumar Sinha, Dipankar Chakraborty and Arun Kumar Ray (1992). Juvenile hormone - Its effect on development and gr5owth of tropical tasar silkworm. Indian Silk, Central Silk Board, Bangalore. pp. 23-25

6. Harjeet Singh \& Ravneet Kour, "Rearing Performance of Bivoltine Hybrids of the Silkworm, Bombyx mori L in Poonch District of Jammu and Kashmir State During Spring Rearing Season”, International Journal of Applied and Natural Sciences (IJANS), Vol. 7, Issue 5, pp; 1-4

7. Chandrakala, M.V. \& Maribashetty, V.G. (2009). Application of hormones in silkworm rearing - tapping the potential. Advances in Mulberry Sericulture. (Eds. M.C. Devaiah, K.C. Narayanaswamy and V.G. Maribashetty) CVG Publications, Bangalore. pp.345-369.

8. V. Lakshmikantham \& D. Bharathi, "Impact of Plant Growth Hormone, Indole-3-Acetic Acid (IAA) on the Organic Constituents of Silkworm, Bombyx mori L”, International Journal of Agricultural Science and Research (IJASR), Vol. 4, Issue 5, $p$, 37-44

9. Chen, E.Y., Feng, H., \& Guo, F. (1982). Effects of juvenile hormone analogue on the protein content and development of the silk gland in the fifth instar silkworms. Insect Knowledge Zhishi., 19(4), 25-28.

10. Chowdhury, S.K., Raju, R.S. and Ogra, R.K. (1990) Effect of JH analogues on silkworm, Bombyx mori L., growth and development of silk gland. Sericologia, 30, 155-165.

11. Chowdhury, S.K., Sehnal, F., Raj, S.K., Raju, P.S. \& Mathu S. (1986). Giant cocoon formation in Bombyx mori L. topically treated with juvenile hormone SJ-42-F. Sericologia, 26, 455-459.

12. Dandin, S.B \& Giridhar K. (2010). Handbook of Sericulture Technologies. Central Silk Board, Bangalore.

13. Gamo, T. (1977). Low molecular weight lipoproteins in the haemolymph of the silkworm, Bombyx mori: inheritance, isolation and some properties. Insect. Biochem., 8, 457-470.

14. Kajiura, Z. \& Yamashita, O. (1989). Super growth of silk glands in the larvae of the silkworm, Bombyx mori, induced by a juvenile hormone analogue. J. Seric. Sci. Japan, 58, 39-46.

15. Kamimura, M. (1995). Effects of juvenile hormone analogue, fenoxycarb, on larval growth of the silkworm, Bombyx mori (Lepidoptera: Bombycidae). Appl. Ent. Zool., 30, 487-489. 
16. Kurata, K., \& Dillies, J. (1978). Effect of exogenous juvenoid on growth of the silk gland and synthesis of nucleic acids and silk protein in the silk gland of Bombyx mori. Bull. Seric. Exp. Stn. Jpn., 27, 507-530.

17. Li, X., Zhu, J. \& Hui, S. (1992). Studies on improving the mounting rate of partitioned cocooning frame by using ecdysone. Bull. Seric., (1), 23-26.

18. Lix, H., Wu, XF. Liu, JM., Li, GL., \& Miao, Y.G. (2006). Proteomic analysis of the silkworm Bombyx mori L. haemolymph during developmental stage. J. Proteome Res. 5, 2809- 2814.

19. Lowry, O.H. Rosenbrough, N.J., Farr, A.L., \& Randall, R.J. (1951) Protein measurement with folin phenol reagent. Journal of Bio-Chemistry, (193), 265- 275.

20. Muroga A., Nakajima M., Aomori S., Ozawa Y. \& Nihmura M. (1975) Utilisation of the synthetic juvenile hormone analogue to the silkworm rearing on mulberry leaves. J. Seric. Sci. Jpn, 44(4), 267-273

21. Naga Jyothi, P., Nagalakshmamma, A., Phaninatha Sarma, A., Suneetha, Y., \& Siva Prasad, S. (2010). Effect of ultrasound on the structural proteins of different tissues of the fifth instar silkworm, Bombyx mori L. Global J. Biotech and Biochem. 5, 136140.

22. Nagata, M. \& Yoshitake, N. (1989). Protein metabolism in the larval development of silkworm, Bombyx mori, protein reutilization at the moult. J. Serico. 58(3), 221-223.

23. Nair, K.S., Vijayan, V.A, Nair, J.S., \& Trivedi, K. (1999) Juvenile mimic compounds for enhanced productivity in silkworm, Bombyx mori L. - A screening. Ind. J. Seri. 38, 119- 124.

24. Nair, K.S., Vijayan, V.A., Nair, J.S., Trivedi, K., \& Chinya, P.K. (2000) Influence of a plant based juvenile hormone mimic, $\omega$ formyl longifolene oxime citronellyl ether on silkworm, Bombyx mori L. Sericologia, 40(4), 551-557

25. Nair K. S., Trivedi K. \& Chinya P. K. (1998) Juvenile hormone mimics and silk productivity. Indian Silk, 37(8), 23-25.

26. Nihmura, M., Aomori, S., Mori K., \& Matsui, M. (1972) Utilization of synthetic compounds with juvenile hormone activity for the silkworm rearing. Agric. Biol. Chem., 36 (5), 889-892.

27. Niimi, S., \& Sakurai, S. (1997) Development changes in juvenile hormone and juvenile hormone acid titers in the haemolymph and in vitro juvenile hormone synthesis by corpora allata of silkworm, Bombyx mori. J. Insect Physiol. 43, 875-884.

28. Ravi Kumar, H. N. \& Sarangi, S. K. (2000). Changes in the concentration of soluble protein and free amino acids during fifth instar development of Eri silkworm, Philosomia ricini. In: Advances in Tropical Sericulture (Eds. S.B. Dandin, R.K. Mishra, V.P. Gupta and Y.S. Reddy). National Academy of Sericulture Sciences India, Bangalore, pp. 433-436.

29. Riddiford, L.M. (1985). Hormonal action at the cellular level. In: Comprehensive Insect Physiology Biochemistry and Pharmacology (ed. Kerkut G.A. and Gilbert L.I.), Pergamon Press, Oxford. pp. 37-84.

30. Sakurai, S., Okuda, M. \& Ohtaki, T. (1989). Juvenile hormone inhibits ecdysone secretion and responsiveness to protharacicotropic hormone in prothoracic glands of Bombyx mori. General and Comparative Endocrinology 75, 22-230.

31. Tazima, Y. (1978) The silkworm: An important laboratory tool. National Institute of Genetics Kodansha Tokyo, Japan.

32. Trivedi, K., Remadevi, O. K., Magadum, S. B. \& Dutta, R. K. (1993). Effect of juvenile hormone analogue labomin on the growth and economic character of silkworm Bombyx mori L., Indian J. Seric. 32, 618-624.

33. Williams, C.M. (1956). The Juvenile hormone of insects. Nature, 178, 212-213 


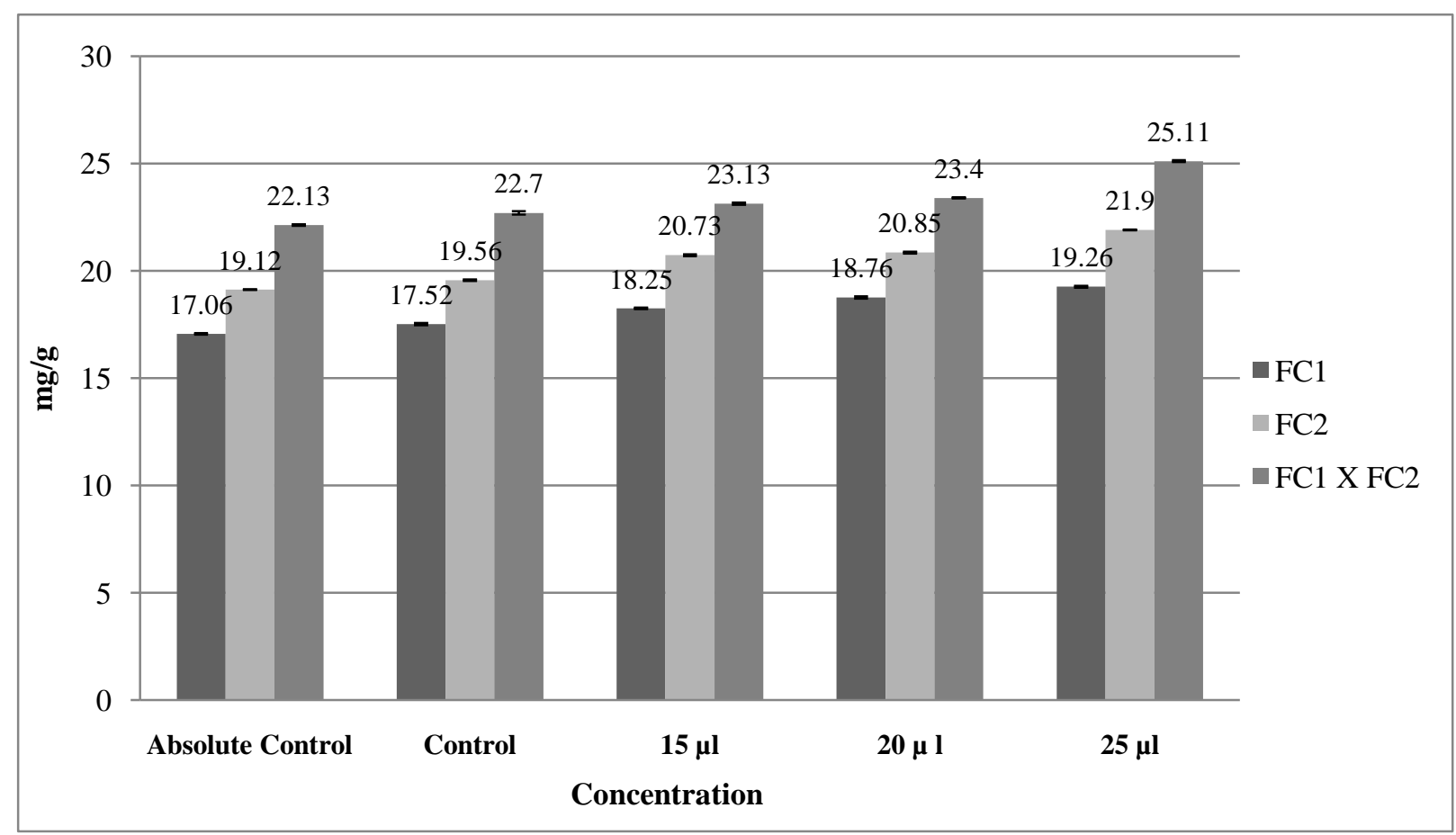

Figure 1: Graph showing the Protein Content (mg/g) in the Larval Fat Body after $24 \mathrm{~h}\left(5^{\text {th }}\right.$ Instar, day 3) Treated with JH using Three Different Concentrations

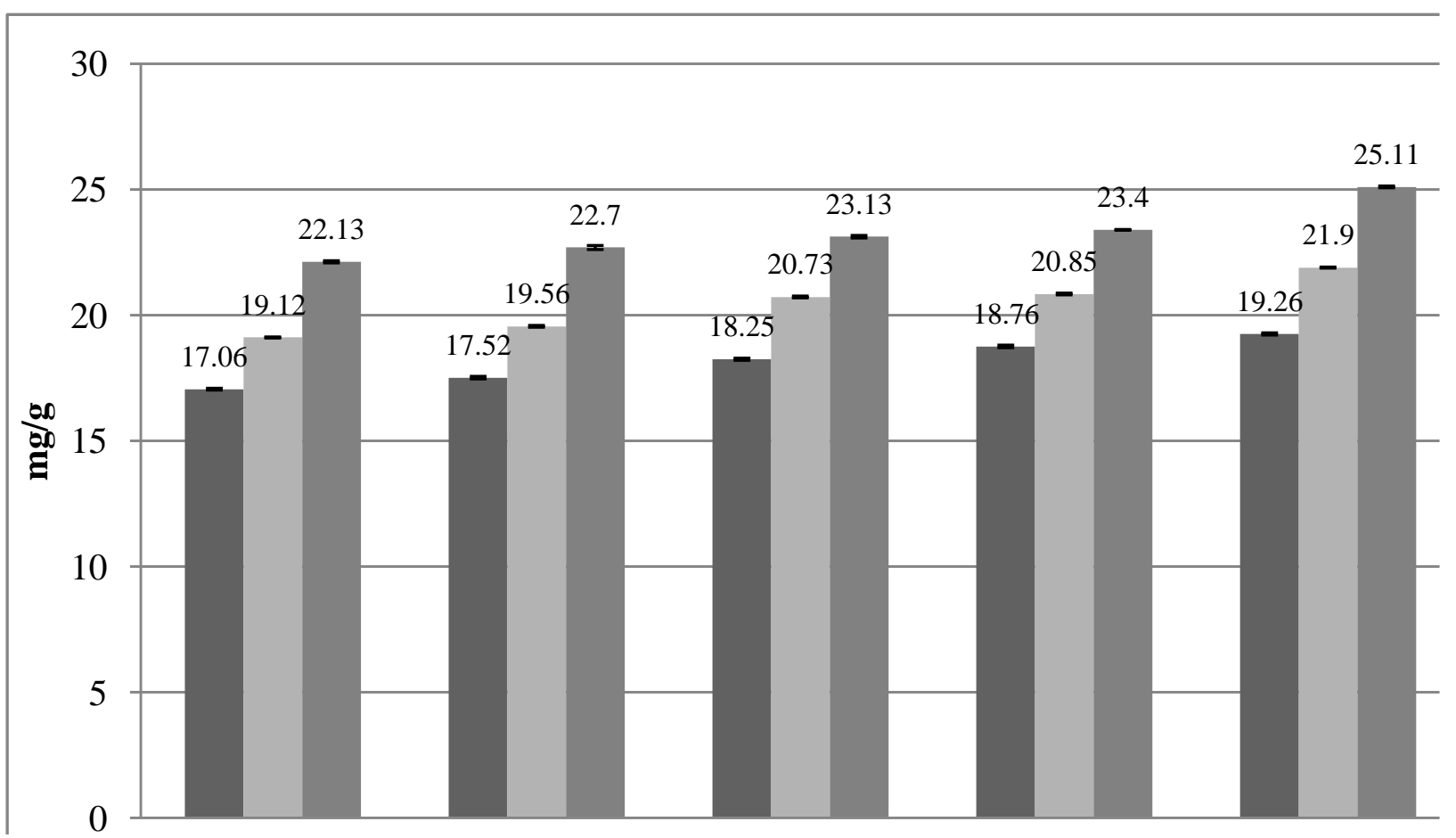

Figure 2: Graph showing the Protein Content (mg/g) in the Larval Fat Body after $48 \mathrm{~h}\left(5^{\text {th }}\right.$ instar, day 3$)$ Treated with JH using three Different Concentrations 


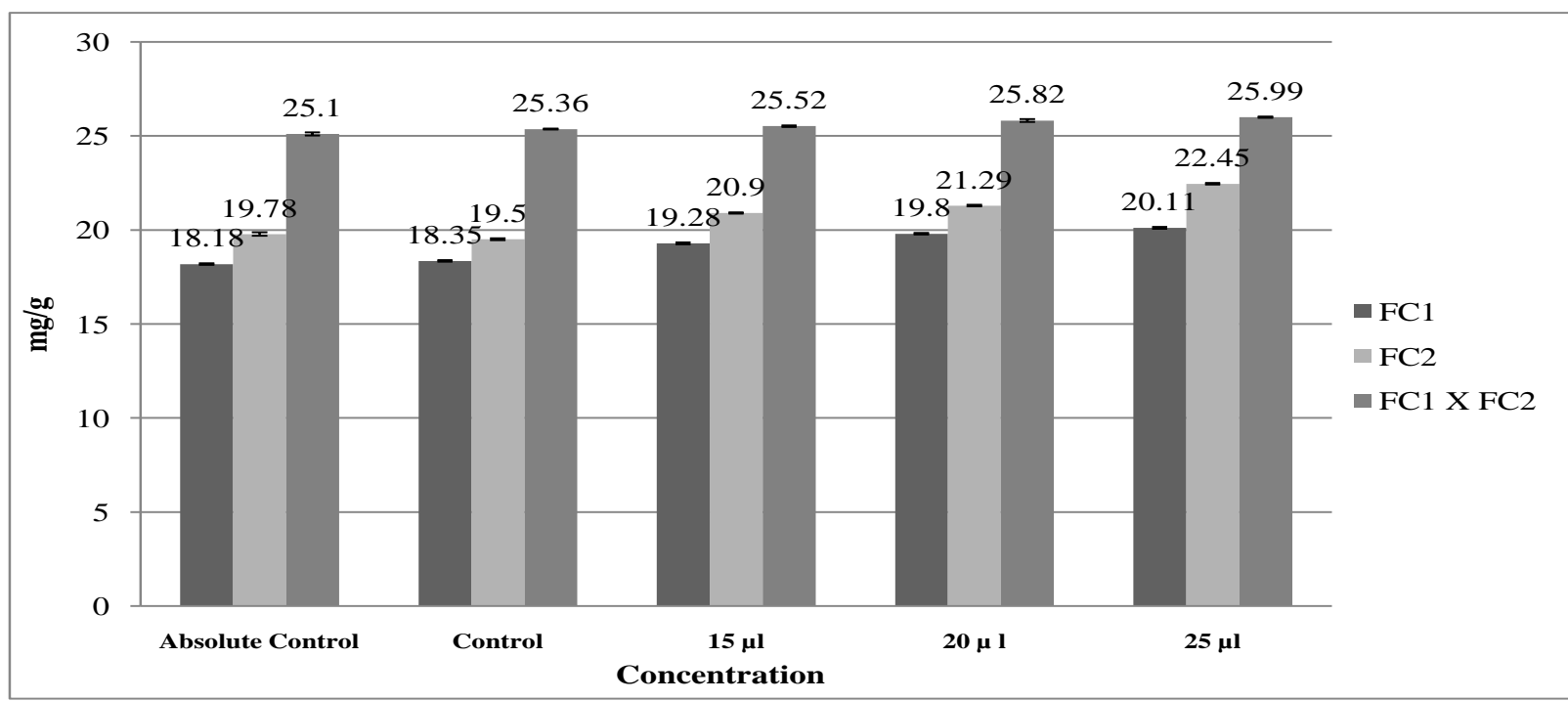

Figure 3: Graph showing the Protein Content (mg/g.) in the Larval Fat Body after $72 \mathrm{~h}\left(5^{\text {th }}\right.$ instar 3 day) Treated with JH using three Different Concentrations

Table 1: Showing the Mean Values of Economic Parameters of Silkworm Rearing of Treatment $\left(3^{\text {rd }}\right.$ day of 5th instar)

\begin{tabular}{|c|c|c|c|c|c|c|c|c|}
\hline $\begin{array}{l}\text { Breeds/ } \\
\text { Hybrids }\end{array}$ & $\begin{array}{c}\text { Treatments } \\
\mu \mathrm{l}\end{array}$ & $\begin{array}{c}\text { Matured } \\
\text { Larval } \\
\text { Weight } \\
\text { (g.) }\end{array}$ & $\begin{array}{c}\text { Larval } \\
\text { Duration } \\
\text { (days) }\end{array}$ & $\begin{array}{c}\text { Cocoon } \\
\text { Weight } \\
\text { (g.) }\end{array}$ & $\begin{array}{c}\text { Shell } \\
\text { Weight } \\
\text { (g.) }\end{array}$ & $\begin{array}{c}\text { Shell } \\
\%\end{array}$ & $\begin{array}{c}\text { Filament } \\
\text { Length } \\
(\mathbf{m} .)\end{array}$ & $\begin{array}{c}\text { Filament } \\
\text { Weight } \\
\text { (g.) }\end{array}$ \\
\hline \multirow{5}{*}{$\mathrm{FC}_{1}$} & $\begin{array}{c}\text { Absolute } \\
\text { control }\end{array}$ & $\begin{array}{c}34.85 \\
\pm 0.011\end{array}$ & 22 & $\begin{array}{c}5.015 \\
\pm 0.004 \\
\end{array}$ & $\begin{array}{c}0.989 \\
\pm 0.005\end{array}$ & $\begin{array}{c}19.72 \\
\pm 0.108\end{array}$ & $\begin{array}{c}1073 \\
\pm 3.606\end{array}$ & $\begin{array}{c}0.725 \\
\pm 0.004\end{array}$ \\
\hline & Control & $\begin{array}{c}34.35 \\
\pm 0.008 \\
\end{array}$ & 22 & $\begin{array}{l}5.023 \\
\pm 0.03\end{array}$ & $\begin{array}{r}1.015 \\
\pm 0.004\end{array}$ & $\begin{array}{l}20.212 \\
\pm 0.087\end{array}$ & $\begin{array}{c}1189 \\
\pm 3.055\end{array}$ & $\begin{array}{c}0.730 \\
\pm 0.005\end{array}$ \\
\hline & 15 & $\begin{array}{c}36.78 \\
\pm 0.016 \\
\end{array}$ & 22 & $\begin{array}{c}6.24 \\
\pm 0.008 \\
\end{array}$ & $\begin{array}{c}1.134 \\
\pm 0.004 \\
\end{array}$ & $\begin{array}{c}20.24 \\
\pm 0.052 \\
\end{array}$ & $\begin{array}{c}1348 \\
\pm 2.517 \\
\end{array}$ & $\begin{array}{c}0.739 \\
\pm 0.002 \\
\end{array}$ \\
\hline & 20 & $\begin{array}{c}38.36 \\
\pm 0.028 \\
\end{array}$ & 22 & $\begin{array}{c}6.359 \\
\pm 0.003 \\
\end{array}$ & $\begin{array}{c}1.312 \\
\pm 0.008 \\
\end{array}$ & $\begin{array}{l}20.763 \\
\pm 0.119\end{array}$ & $\begin{array}{c}1379 \\
\pm 6.028\end{array}$ & $\begin{array}{c}0.742 \\
\pm 0.003 \\
\end{array}$ \\
\hline & 25 & $\begin{array}{c}38.57 \\
\pm 0.005\end{array}$ & 22 & $\begin{array}{c}6.722 \\
\pm 0.006 \\
\end{array}$ & $\begin{array}{c}1.353 \\
\pm 0.004\end{array}$ & $\begin{array}{c}20.68 \\
\pm 0.102\end{array}$ & $\begin{array}{c}1415 \\
\pm 4.509\end{array}$ & $\begin{array}{c}0.750 \\
\pm 0.003\end{array}$ \\
\hline \multirow{5}{*}{$\mathrm{FC}_{2}$} & $\begin{array}{c}\text { Absolute } \\
\text { control }\end{array}$ & $\begin{array}{c}35.19 \\
\pm 0.003\end{array}$ & 22 & $\begin{array}{c}5.126 \\
\pm 0.005\end{array}$ & $\begin{array}{c}1.183 \\
\pm 0.003\end{array}$ & $\begin{array}{l}23.081 \\
\pm 0.060\end{array}$ & $\begin{array}{c}1234 \\
\pm 4.583\end{array}$ & $\begin{array}{c}0.813 \\
\pm 0.003\end{array}$ \\
\hline & Control & $\begin{array}{c}35.22 \\
\pm 0.003 \\
\end{array}$ & 22 & $\begin{array}{c}5.207 \\
\pm 0.007\end{array}$ & $\begin{array}{r}1.215 \\
\pm 0.002\end{array}$ & $\begin{array}{l}23.351 \\
\pm 0.040 \\
\end{array}$ & $\begin{array}{c}1230 \\
\pm 2.000 \\
\end{array}$ & $\begin{array}{c}0.816 \\
\pm 0.003 \\
\end{array}$ \\
\hline & 15 & $\begin{array}{c}38.17 \\
\pm 0.033 \\
\end{array}$ & 22 & $\begin{array}{c}6.217 \\
\pm 0.006 \\
\end{array}$ & $\begin{array}{c}1.349 \\
\pm 0.004 \\
\end{array}$ & $\begin{array}{r}23.56 \\
\pm 0.061 \\
\end{array}$ & $\begin{array}{c}1322 \\
\pm 4.509 \\
\end{array}$ & $\begin{array}{c}\mathbf{0 . 8 3 2} \\
\pm \mathbf{0 . 0 0 3} \\
\end{array}$ \\
\hline & 20 & $\begin{array}{c}38.95 \\
\pm 0.014 \\
\end{array}$ & 22 & $\begin{array}{c}6.132 \\
\pm 0.002 \\
\end{array}$ & $\begin{array}{c}1.487 \\
\pm 0.006 \\
\end{array}$ & $\begin{array}{l}24.248 \\
\pm 0.085 \\
\end{array}$ & $\begin{array}{c}1388 \\
\pm 4.509 \\
\end{array}$ & $\begin{array}{c}0.855 \\
\pm 0.006 \\
\end{array}$ \\
\hline & 25 & $\begin{array}{c}38.98 \\
\pm 0.005 \\
\end{array}$ & $22,3 \mathrm{~h}$ & $\begin{array}{c}6.548 \\
\pm 0.009 \\
\end{array}$ & $\begin{array}{c}1.437 \\
\pm 0.004 \\
\end{array}$ & $\begin{array}{l}24.939 \\
\pm 0.054 \\
\end{array}$ & $\begin{array}{c}1433 \\
\pm 3.055 \\
\end{array}$ & $\begin{array}{c}0.871 \\
\pm 0.002 \\
\end{array}$ \\
\hline \multirow{5}{*}{$\begin{array}{c}\mathbf{F C}_{1} \mathbf{X} \\
\mathrm{FC}_{2}\end{array}$} & $\begin{array}{c}\text { Absolute } \\
\text { Control }\end{array}$ & $\begin{array}{c}35.28 \\
\pm 0.008 \\
\end{array}$ & 22 & $\begin{array}{c}5.409 \\
\pm 0.008 \\
\end{array}$ & $\begin{array}{c}1.225 \\
\pm 0.005 \\
\end{array}$ & $\begin{array}{l}22.647 \\
\pm 0.106 \\
\end{array}$ & $\begin{array}{c}1294 \\
\pm 2.000 \\
\end{array}$ & $\begin{array}{c}0.816 \\
\pm 0.004 \\
\end{array}$ \\
\hline & Control & $\begin{array}{c}35.34 \\
\pm 0.016 \\
\end{array}$ & 22 & $\begin{array}{c}5.35 \\
\pm 0.052 \\
\end{array}$ & $\begin{array}{c}1.216 \\
\pm 0.005\end{array}$ & $\begin{array}{l}22.833 \\
\pm 0.090\end{array}$ & $\begin{array}{c}1356 \\
\pm 3.055 \\
\end{array}$ & $\begin{array}{c}\mathbf{0 . 8 2 4} \\
\pm \mathbf{0 . 0 5 7} \\
\end{array}$ \\
\hline & 15 & $\begin{array}{c}38.23 \\
\pm 0.008 \\
\end{array}$ & 22 & $\begin{array}{c}6.43 \\
\pm 0.004 \\
\end{array}$ & $\begin{array}{c}1.465 \\
\pm 0.030\end{array}$ & $\begin{array}{c}23.56 \\
\pm 0.061\end{array}$ & $\begin{array}{c}1334 \\
\pm 3.000\end{array}$ & $\begin{array}{c}0.841 \\
\pm 0.004\end{array}$ \\
\hline & 20 & $\begin{array}{c}39.23 \\
\pm 0.004 \\
\end{array}$ & 22 & $\begin{array}{c}6.394 \\
\pm 0.005 \\
\end{array}$ & $\begin{array}{c}1.511 \\
\pm 0.026 \\
\end{array}$ & $\begin{array}{l}24.248 \\
\pm 0.085\end{array}$ & $\begin{array}{c}1410 \\
\pm 5.000\end{array}$ & $\begin{array}{c}0.912 \\
\pm 0.004 \\
\end{array}$ \\
\hline & 25 & $\begin{array}{c}39.25 \\
\pm 0.007 \\
\end{array}$ & $22,6 \mathrm{~h}$ & $\begin{array}{c}6.917 \\
\pm 0.008 \\
\end{array}$ & $\begin{array}{c}1.508 \\
\pm 0.066\end{array}$ & $\begin{array}{r}24.797 \\
\pm 0.930 \\
\end{array}$ & $\begin{array}{c}1497 \\
\pm 3.606 \\
\end{array}$ & $\begin{array}{c}0.920 \\
\pm 0.005\end{array}$ \\
\hline
\end{tabular}

$(\mathbf{P}<\mathbf{0 . 0 5})$ 